\title{
Socioeconomic status in HCV infected patients - risk and prognosis
}

This article was published in the following Dove Press journal:

Clinical Epidemiology

30 May 2013

Number of times this article has been viewed

\author{
Lars Haukali Omland' \\ Merete Osler ${ }^{2}$ \\ Peter Jepsen ${ }^{3,4}$ \\ Henrik Krarup ${ }^{5}$ \\ Nina Weis ${ }^{6}$ \\ Peer Brehm Christensen ${ }^{7}$ \\ Casper Roed' \\ Henrik Toft Sørensen ${ }^{3}$ \\ Niels Obel'

\section{On behalf of the DANVIR Cohort Study} \\ 'Department of Infectious Diseases, \\ Copenhagen University Hospital, \\ Rigshospitalet, Copenhagen, Denmark; \\ ${ }^{2}$ Research Center for Prevention \\ and Health, Copenhagen University \\ Hospital, Glostrup Hospital, \\ Glostrup, Denmark; ${ }^{3}$ Department \\ of Clinical Epidemiology, Aarhus \\ University Hospital, Aarhus, \\ Denmark; ${ }^{4}$ Department of Medicine V \\ (Hepatology and Gastroenterology), \\ Aarhus University Hospital, Aarhus, \\ Denmark; ${ }^{5}$ Department of Clinical \\ Biochemistry, Aalborg Hospital, \\ Aalborg, Denmark; ${ }^{6}$ Department \\ of Infectious Diseases, Copenhagen \\ University Hospital, Hvidovre \\ Hospital, Hvidovre, Denmark; \\ ${ }^{7}$ Department of Infectious Diseases, \\ Odense University Hospital, Odense, \\ Denmark
}

Correspondence: Lars Haukali Omland Department of Infectious Diseases, Rigshospitalet, Blegdamsvej 9, DK2 100 Copenhagen $\varnothing$, Denmark

Tel +453545 7726

Fax +45 35456648

Email omland@dadlnet.dk
Background and aims: It is unknown whether socioeconomic status (SES) is a risk factor for hepatitis C virus (HCV) infection or a prognostic factor following infection.

Methods: From Danish nationwide registries, we obtained information on three markers of SES: employment, income, and education. In a case control design, we examined HCV infected patients and controls; conditional logistic regression was employed to obtain odds ratios (ORs) for HCV infection for each of the three SES markers, adjusting for the other two SES markers, comorbidity, and substance abuse. In a cohort design, we used Cox regression analysis to compute mortality rate ratios (MRRs) for each of the three SES markers, adjusting for the other two SES markers, comorbidity level, age, substance abuse, and gender.

Results: When compared to employed persons, ORs for HCV infection were 2.71 (95\% confidence interval [CI]: 2.24-3.26) for disability pensioners and 2.24 (95\% CI: 1.83-2.72) for the unemployed. When compared to persons with a high income, ORs were 1.64 (95\% CI: 1.34-2.01) for low income persons and 1.19 (95\% CI: 1.02-1.40) for medium income persons. The OR was 1.35 (95\% CI: 1.20-1.52) for low education (no more than basic schooling). When compared to employed patients, MRRs were 1.71 (95\% CI: 1.22-2.40) for unemployed patients and 2.24 (95\% CI: 1.63-3.08) for disability pensioners. When compared to high income patients, MRRs were 1.47 (95\% CI: 1.05-2.05) for medium income patients and 1.64 (95\% CI: 1.13-2.34) for low income patients. Educational status was not associated with mortality.

Conclusion: Low SES was associated with an increased risk of HCV infection and with poor prognosis in HCV infected patients.

Keywords: survival, socioeconomic status, risk factor, prognosis

\section{Introduction}

The hepatitis $C$ virus (HCV) is a linear, single stranded RNA virus and was established as the cause of non-A, non-B hepatitis in $1989 .{ }^{1}$ With 170 million persons infected worldwide, $\mathrm{HCV}$ infection poses serious challenges to global health. ${ }^{2} \mathrm{HCV}$ infection is primarily a hepatotropic virus, but the virus also infects cells of the lymphatic system. ${ }^{3}$ Consequently, HCV infection is associated with substantial morbidity and mortality. ${ }^{4-10}$ Nonetheless, when comparing mortality between HCV infected patient and the general population $^{4,7,9}$ and between patients with chronic and cleared HCV infection, ${ }^{8,11,12}$ there seems to be a discrepancy in increased mortality. This could indicate that not only the virus, but that also other factors may increase mortality in HCV infected individuals, a hypothesis that is supported by an enormously increased mortality among patients with cleared $\mathrm{HCV}$ infection when compared to the general population. ${ }^{13}$ The main route of $\mathrm{HCV}$ infection is injection drug use (IDU), and IDU is likely to explain a 
substantial proportion of the increased mortality in HCV infected patients. This hypothesis is supported by cause of death analyses among HCV infected patients. ${ }^{4,9,14}$ However, IDU is generally considered as unaccepted behavior leading to stigma, and therefore, IDU is often not disclosed in a patient-doctor relationship..$^{15,16}$

Socioeconomic status (SES) refers to an individual's position in society and may be based on criteria such as education, occupation, income, and value of dwelling place. ${ }^{17}$ Cross-sectional studies from the United States, Puerto Rico, Norway, and France have found associations between different SES markers and prevalence of HCV infection. ${ }^{18-22}$ The following markers of SES were tested: "receipt of beneficiaries of medical welfare for precarious persons", "employment", "education", "stay in institutions or prisons", "marital status", "income" and "ethnicity". ${ }^{18-22}$ Even after adjusting for illicit drug use and other risk factors related to route of infection, these studies found an increased risk of $\mathrm{HCV}$ infection in persons with low SES. ${ }^{18,20-22}$ However, these studies relied on surveys as the source of information on exposure, and as such were subjected to nondisclosure and recall bias. ${ }^{23}$ Thus far, no studies using a population based nationwide design based on established national registries have examined whether $\mathrm{HCV}$ infection is associated with SES at the individual level. Further, it remains important to clarify whether SES is associated with survival in HCV infected patients, as it is for patients with alcoholism, ${ }^{24}$ cancer, ${ }^{25,26}$ cardiovascular diseases ${ }^{27-30}$ and cirrhosis. ${ }^{31}$

Thus, we undertook a population based study to investigate markers of SES in HCV infected patients. We focused on occupational status, income, and educational status to address the following question: is low SES associated with an increased risk of $\mathrm{HCV}$ infection and a poor prognosis following infection?

\section{Patients and methods}

\section{Substudy I - risk of HCV infection}

This case control design addressed whether persons with low SES were at higher risk of HCV infection than persons with favorable SES (ie, employed persons with a personal income of $75 \%$ of the national average or higher, and with an educational level above basic schooling).

\section{Substudy 2 - mortality after a diagnosis of HCV infection}

This cohort design addressed whether low SES was associated with high mortality among HCV infected patients.

\section{Setting}

Denmark has a population of 5.4 million, ${ }^{32}$ with an estimated HCV prevalence of $0.4 \% .{ }^{33}$ Most people in Denmark finish their higher education between the age of 25 and 30 years, but some would extend their education into their $30 \mathrm{~s}$. $\mathrm{HCV}$ infected patients are treated in hospital departments that specialize in infectious diseases, gastroenterology, or hepatology. ${ }^{34}$ Medical care, including antiviral treatment, is provided free of charge to all Danish residents. In 2000 to 2001 approximately 5\% of the workforce aged $40-59$ years was unemployed. ${ }^{35}$

\section{Data sources}

We used the unique ten digit civil registration number assigned to all Danish residents ${ }^{36}$ to link individual level data from the following data sources.

Danish HCV cohort (DANVIR): HCV infected patients were identified from the DANVIR cohort, which comprises all patients tested for $\mathrm{HCV}$ in 14 of the 18 laboratories that perform such testing in Denmark. ${ }^{8,9}$ DANVIR data includes dates and results of HCV antibody tests (from 1991 onward) and HCV RNA tests (from 1995 onward). While HCV antibody tests are performed in all participating DANVIR centers, most HCV RNA measurements are done in the Department of Clinical Biochemistry, Aalborg University Hospital. ${ }^{37}$ When the DANVIR cohort was established, it was estimated to include more than $90 \%$ of all Danish patients tested for HCV RNA and the majority of patients tested for HCV antibodies. ${ }^{8,9,38}$

The Integrated Database for Labor Market Research (IDA): Occupational status and income were extracted from the IDA, which is maintained by Statistics Denmark and covers the entire population of Denmark. ${ }^{39}$ Data on income have been updated annually since 1980 and data on employment since 1994 for all tax eligible persons in Denmark. ${ }^{40,41}$ The main employment categories are "selfemployed," "employed," and "unemployed," each with several subcategories.

The Educational Attainment Register (EAR): We extracted data on educational status from the EAR, which was established in 1974. This registry contains data on the educational status of the entire Danish population. ${ }^{42}$ The registry collects data from all educational institutions in the country, from elementary schools to universities, as well as parttime educational programs and educational programs outside of Denmark.

Civil Registration System (CRS): The CRS, which was established in 1968, maintains information on vital status 
and migration for all Danish residents. ${ }^{36}$ We used this data source to identify a control group in substudy 1 and to obtain dates of death and migration.

Danish National Registry of Patients (DNRP): The DNRP, established in 1977, collects information on all nonpsychiatric hospital admissions in Denmark. Data from outpatient and emergency department visits were added in 1995. For each hospital contact, the DNRP records dates of admission and discharge, and up to 20 discharge diagnoses, assigned by physicians and coded according to the International Classification of Diseases, 8th revision (ICD-8) ${ }^{43}$ through 1993 and the 10th version (ICD-10) ${ }^{44}$ from 1994 onwards. ${ }^{45}$ We extracted data from the DNRP on comorbidity and substance abuse, using diagnoses from inpatient hospitalizations, outpatient visits, and emergency room visits. ${ }^{8}$

The Registry of Drug Abusers Undergoing Treatment has registered all individuals in Denmark undergoing treatment for drug addiction since $1996 .{ }^{46}$ Treatment of drug addiction in Denmark is restricted to referral centers, which must supply data to the registry in order to obtain funding.

\section{Study population}

\section{Substudy I - risk of HCV infection}

In this case control design, cases were defined as HCV infected patients who (1) were registered in DANVIR with a positive HCV antibody and/or HCV RNA test; (2) were born in Denmark; (3) were aged between 40 and 60 years at diagnosis of $\mathrm{HCV}$; (4) were registered in DANVIR with a diagnosis of HCV infection between January 1, 1999 and December 31, 2006; and (5) had no previous diagnosis of HCV infection prior to January 1, 1999 in DANVIR or the DNRP (ICD-10 codes B17.1 or 18.2). The age restriction was applied to select patients who had finished education. Patients with missing data on income or occupation $(n=8)$ were excluded. We used risk set sampling to identify the control group. For each HCV infected patient, we included five randomly selected individuals from the general population matched on age and sex. ${ }^{47}$

\section{Substudy 2 - mortality after a diagnosis of HCV infection}

Substudy 2, in which we analyzed the impact of SES on mortality, included only $\mathrm{HCV}$ infected patients.

\section{Categorization of SES variables and covariates SES}

We used three indicators to measure SES in the calendar year preceding study inclusion: (1) primary occupation,
(2) taxable personal income, and (3) educational attainment. We categorized study participants into one of three occupational categories: employed persons (self-employed, executive or highly qualified employees, and employees with lower qualifications), unemployed persons (including those in educational programs), and persons receiving a disability pension. The disability pension, which is granted to persons with a permanent limitation in their ability to work, ${ }^{48,49}$ was used as an occupational category due to the unusually high number of $\mathrm{HCV}$ infected patients falling into this category. Income was categorized into three categories on the basis of taxable income: $0 \%-49 \%, 50 \%-74 \%$, and $>75 \%$ of the national average for persons of the same sex and age (in 5-year age categories). Education was computed as the highest level of education registered in the EAR, grouped into the following two categories: basic schooling (sixth grade) or higher education.

\section{Substance abuse}

We defined substance abuse as a diagnosis of alcohol abuse and/or IDU on or before the date of study inclusion. Alcohol abuse was defined as a record of one or more diagnoses suggesting alcohol abuse in the DNRP (see Supplementary material 1 for details). IDU was defined as inclusion in the Registry of Drug Abusers Undergoing Treatment and/or a record of one or more diagnoses suggesting IDU in the DNRP (see Supplementary material 1 for details).

\section{Comorbidity}

We calculated the Charlson Comorbidity Index (CCI) score derived from diagnoses registered in the DNRP before the index date. ${ }^{50,51}$ The positive predictive value of diagnosis coding in the DNRP for conditions included in the CCI is very high. ${ }^{52}$ The CCI assigns a score between one and six to a range of diseases, with the sum of individual scores serving as a measure of patients' overall comorbidity. We identified comorbid diseases using the ICD-10 codes provided by Quan et $\mathrm{al}^{53}$ (matching ICD-8 codes to ICD-10 codes as closely as possible, see Supplementary material 2 for details). In the present study, liver diseases were regarded as complications in the causal pathway of HCV infection and were therefore not included in the CCI. We used three comorbidity levels: none (CCI score $=0$ ), medium $($ CCI score $=1-2)$, and high $($ CCI score $>2$ ).

\section{Statistical analysis}

\section{Substudy I - risk of HCV infection}

Analyses focused on employment, income, and education, as defined above for the calendar year preceding the 
$\mathrm{HCV}$ diagnosis. We used conditional logistic regression to obtain odds ratios (ORs) for HCV infection for each of the three SES markers, adjusting for the other two SES markers, comorbidity level, and substance abuse. ${ }^{54}$ Because HCV infection often precedes HCV diagnosis by several years due to the subclinical nature of the acute infection, low SES could be a consequence of HCV infection. For this reason, we reran the conditional logistic regression model replacing SES status during the year before HCV diagnosis with SES status 7 years before diagnosis. Because this yielded essentially the same results, we retained the SES variable values for the year before HCV diagnosis in the final model.

\section{Substudy 2 - mortality after a diagnosis of HCV infection}

In substudy $2, \mathrm{HCV}$ infected patients were followed from the date of HCV diagnosis to death, emigration, or January 1, 2010, whichever came first. Patients were censored in the survival analyses in case they emigrated as we could no longer keep track of them by use of the Danish national registries. The study outcome was survival time. Analyses were based on three SES markers for the calendar year preceding the HCV diagnosis: employment, income, and education, as defined above. We used Cox proportional hazards regression to compute hazard ratios as an estimate for mortality rate ratios (MRR) for each level of each of the three SES markers, adjusting for the other two markers, as well as for comorbidity level, age at HCV infection, substance abuse (yes/no), and gender. Using Schoenfeld residuals, we determined that the hazard ratios were constant over the follow-up time.

We computed survival probabilities using the KaplanMeier method, illustrating survival in each of the nine categories defined by the combination of the three employment categories and the three income categories. We did not illustrate survival according to educational status, as the initial analysis demonstrated that educational status was not associated with survival.

\section{Approvals and permissions}

The Danish Data Protection Agency approved the study (record no 2007-41-0775).

\section{Results}

\section{Characteristics of HCV infected patients and controls}

We identified 3016 Danish HCV infected patients (Table 1). Of these, $1991(66.0 \%)$ were male and the median age was
Table I Characteristics of the 3016 hepatitis C virus (HCV) infected patients and the 15,080 controls

\begin{tabular}{|c|c|c|c|c|}
\hline & \multicolumn{2}{|c|}{$\begin{array}{l}\text { HCV infected } \\
\text { patients }\end{array}$} & \multicolumn{2}{|l|}{ Controls } \\
\hline & Number & $\begin{array}{l}\text { Percent } \\
\text { of total }\end{array}$ & Number & $\begin{array}{l}\text { Percent } \\
\text { of total }\end{array}$ \\
\hline Total & 3016 & 100 & 15,080 & 100 \\
\hline Male & |99| & 66.0 & 9955 & 66.0 \\
\hline \multicolumn{5}{|c|}{ Income in percent of national average* } \\
\hline $0 \%-49 \%$ & 1512 & 50.1 & 1774 & 11.7 \\
\hline $50 \%-74 \%$ & 755 & 25.0 & 3017 & 20.0 \\
\hline$>75 \%$ & 749 & 24.8 & 10,289 & 68.2 \\
\hline \multicolumn{5}{|l|}{ Employment } \\
\hline Employed & 939 & 31.1 & 12,659 & 83.9 \\
\hline $\begin{array}{l}\text { Unemployed/ } \\
\text { seeking education }\end{array}$ & 691 & 22.9 & $|23|$ & 8.2 \\
\hline $\begin{array}{l}\text { Disability } \\
\text { pensioner }\end{array}$ & 1386 & 46.0 & 1190 & 7.9 \\
\hline \multicolumn{5}{|l|}{ Education } \\
\hline $\begin{array}{l}\text { Basic schooling } \\
\text { (sixth grade) }\end{array}$ & 1830 & 60.7 & 4396 & 29.2 \\
\hline Higher education & 1186 & 39.3 & 10,684 & 70.8 \\
\hline \multicolumn{5}{|l|}{ Comorbidity } \\
\hline None $($ score $=0$ ) & 2248 & 74.5 & 13,335 & 88.4 \\
\hline $\begin{array}{l}\text { Medium } \\
(\text { score }=1-2)\end{array}$ & 554 & 18.4 & $|52|$ & 10.1 \\
\hline High (score $\geq 2$ ) & 214 & 7.1 & 224 & 1.5 \\
\hline \multicolumn{5}{|l|}{ Substance abuse } \\
\hline No & 1348 & 44.7 & $|4,7| 8$ & 97.6 \\
\hline Yes & 1668 & 55.3 & 362 & 2.4 \\
\hline Alcohol abuse & 220 & 7.3 & 261 & 1.7 \\
\hline Drug abuse & 1135 & 37.6 & 66 & 0.4 \\
\hline $\begin{array}{l}\text { Drug and } \\
\text { alcohol abuse }\end{array}$ & 313 & 10.4 & 35 & 0.2 \\
\hline
\end{tabular}

Note: *For same sex and age (in 5-year categories).

47 years (interquartile range $=44-51$ years). When compared with the 15,080 population controls, HCV infected patients were more likely to have an income below $50 \%$ of the national average (50.1\% versus $11.7 \%)$, to be disability pensioners $(46.0 \%$ versus $7.9 \%$ ), to have completed only basic schooling $(60.7 \%$ versus $29.2 \%)$, to have comorbidity $(25.5 \%$ versus $11.6 \%)$, and to have substance abuse $(55.3 \%$ versus $2.4 \%$ ) (Table 1 ).

\section{Substudy I - risk of HCV infection}

All three SES markers were associated with risk of $\mathrm{HCV}$ infection (Figure 1). When compared to employed persons, disability pensioners had a 2.71 fold increased risk of diagnosis with $\mathrm{HCV}$ infection ( $95 \%$ confidence interval [CI]: 2.24-3.26), and unemployed persons had a 2.24 fold increased risk (95\% CI: 1.83-2.72). When compared to those with a high income ( $>75 \%$ of the national average), those with a low income $(0 \%-49 \%$ of the national average) 


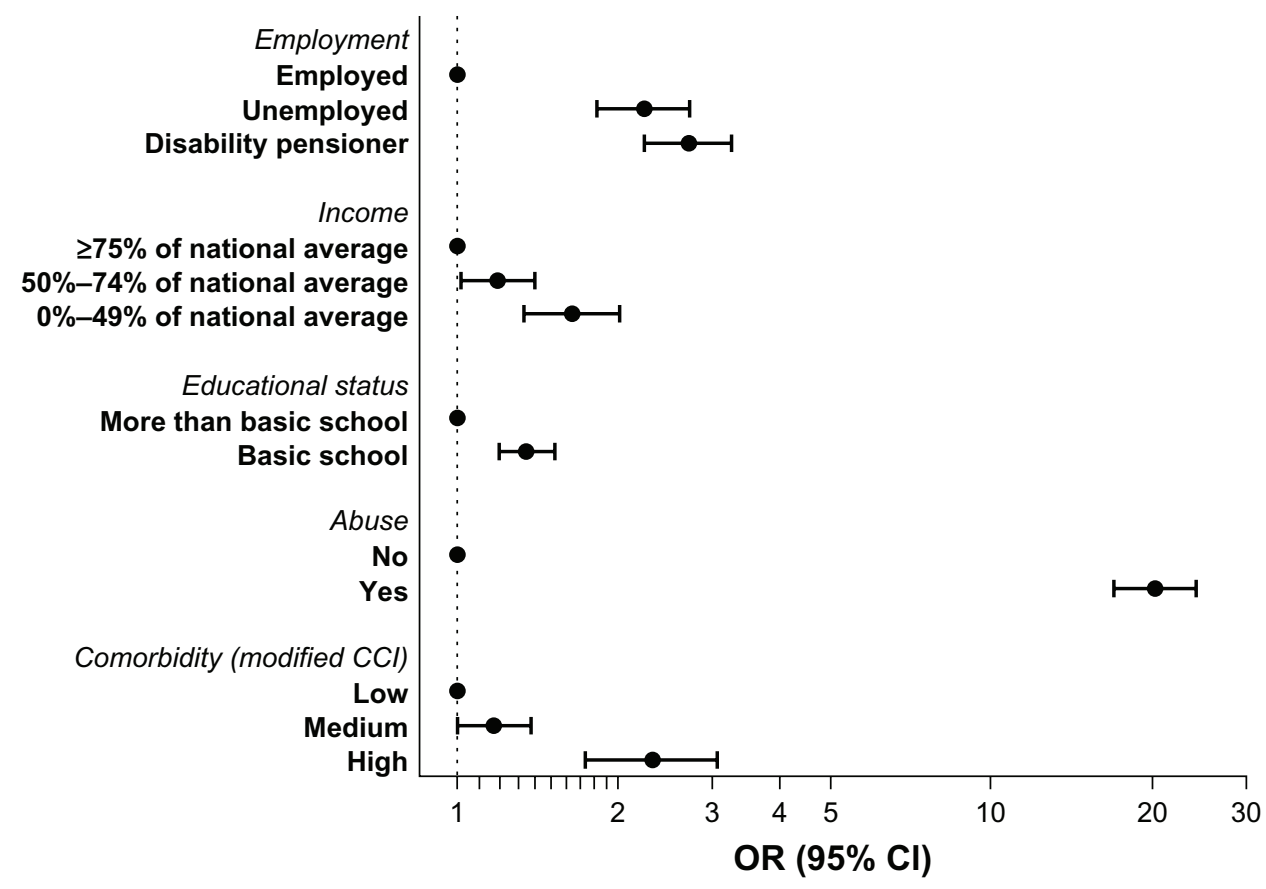

Figure I Odds ratios for being diagnosed with hepatitis $C$ virus according to employment, income, and educational level. Note: Odds ratios for each variable are adjusted for the other variables in the figure.

Abbreviations: $\mathrm{CCl}$, Charlson Comorbidity Index; $\mathrm{Cl}$, confidence intervals; OR, odds ratio.

had a 1.64 fold increased risk of $\mathrm{HCV}$ infection $(95 \% \mathrm{CI}$ : 1.34-2.01), while those with a medium income (50\%-74\% of the national average) had a 1.19 fold increased risk $(95 \%$ CI: 1.02-1.40). Having a low education (basic schooling to sixth grade level) was associated with a 1.35 fold increased risk of HCV infection (95\% CI: 1.20-1.52), when compared with attainment of higher education.

\section{Substudy 2 - mortality after a diagnosis of HCV infection}

When compared to employed patients, mortality was increased among unemployed patients (MRR: $1.71,95 \% \mathrm{CI}$ : 1.22-2.40) and disability pensioners (MRR: 2.24, 95\% CI: 1.63-3.08). Regardless of income, employed patients had a higher 8-year survival rate than unemployed patients and those with a disability pension. Unemployed patients had a higher 8-year survival rate than patients receiving disability pensions (Figure 2).

Income also was associated with mortality. When compared to patients with an income at or above $75 \%$ of the national average, mortality was higher in patients with an income between $50 \%$ and $74 \%$ of the national average (MRR: 1.47, 95\% CI: 1.05-2.05) and in patients with an income between $0 \%$ and $49 \%$ of the national average (MRR: 1.64 , 95\% CI: 1.13-2.34). Generally, patients in the highest income category had a higher 8-year survival rate than patients in the middle and lowest income categories (Figure 3). Educational status was not associated with prognosis. The MRR was 1.01 (95\% CI: 0.86-1.18).

\section{Discussion}

In this combined population based case control and cohort study, we have shown that low SES is associated with an increased risk of $\mathrm{HCV}$ infection, and that once infected, patients with low SES have higher mortality.

The study strengths were inclusion of nearly all Danes testing positive for $\mathrm{HCV}$ infection, as well as having a long and complete follow-up. Use of routinely collected nationwide administrative data on SES and hospitalization history ensured that high quality data were collected independently of our study. This further reduced the risk of bias due to differences in data validity.

The main limitation of our study was its reliance on national registries to capture substance abuse. Our clinical experience indicates that most $\mathrm{HCV}$ infected patients are, or have been, IDUs. Yet, in our study only $50 \%$ of patients were registered as IDUs. Of the remaining 50\% not registered as IDUs, we speculate that the majority are in fact also IDUs and thereby misclassified. ${ }^{55}$ The National Board of Health has estimated that only $33 \%-50 \%$ of the supposed 13,000 IDUs are registered in The Registry of Drug Abusers Undergoing Treatment. ${ }^{56}$ Although these figures are not 


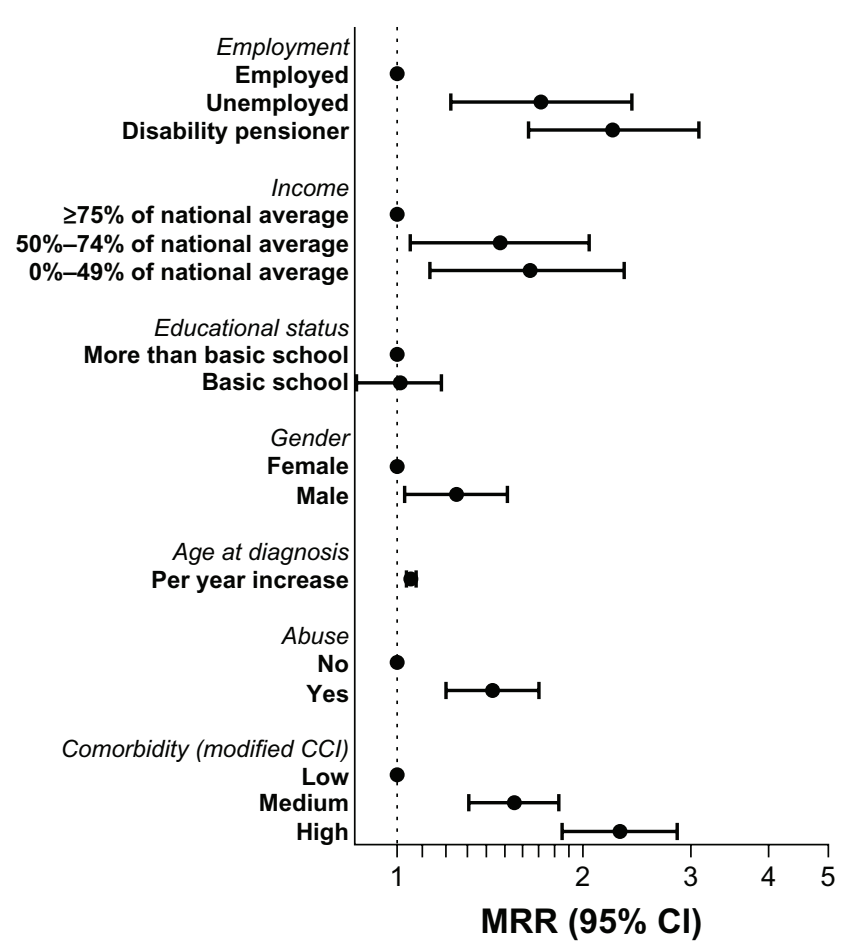

Figure 2 The association between socioeconomic status and survival in hepatitis $C$ virus infected patients.

Note: Associations are expressed as mortality rate ratios, with associated $95 \%$ confidence intervals. Mortality rate ratios for each variable are adjusted for the other variables in the figure.

Abbreviations: $\mathrm{CCl}$, Charlson Comorbidity Index; $\mathrm{Cl}$, confidence intervals; MMR, mortality rate ratio.

directly comparable, they indicate that a large proportion of IDUs are not registered in national registries. We also missed cases of alcohol abuse not leading to hospital contacts and therefore not recorded in the DNRP. Furthermore, because of our reliance on national registries, we were unable to distinguish former from current substance abusers. We were also unable to quantify the level of substance abuse (alcohol and IDU). Another concern is that we included HCV RNA positive and/or HCV antibody positive patients. Some of the $\mathrm{HCV}$ antibody positive patients have cleared their infections. While clearance is associated with improved survival, ${ }^{8}$ it is unlikely that the effect of SES differs according to whether or not the infection was cleared. Finally, we lacked data on antiviral treatment and liver transplantation, so we could not address issues of compliance with these interventions and their effects.

Our finding that low SES is associated with increased risk of HCV infection is consistent with cross-sectional studies from United States, Puerto Rico, Norway, and France, which found associations between various SES markers and prevalence of HCV infection. ${ }^{18-22}$ As expected, IDU was consistently and strongly associated with HCV infection. Even after adjusting for illicit drug use, these studies found an increased risk of HCV infection in patients with low SES. ${ }^{18,20-22}$ Our study adds validity to these findings by producing essentially the same results using data from national registries instead of surveys. The mechanism underlying the increased risk of $\mathrm{HCV}$ infection among patients with low SES is poorly understood. ${ }^{22}$ It is possible that undocumented IDU in persons with low SES could explain the association. ${ }^{20}$ Also, low SES could be a consequence of HCV infection, since HCV infection often precedes diagnosis by several years due to the subclinical nature of the acute infection. However, our analysis has shown that SES did not change substantially up to 7 years before $\mathrm{HCV}$ diagnosis, and the associations did not change when we focused on SES markers measured 7 years before HCV diagnosis (data not shown).

Even in the absence of a causal relation between low SES and $\mathrm{HCV}$ infection, and despite concerns of the temporal relationship between SES and HCV infection, our study has clinical and public health implications. In the absence of a known history of IDU or other high risk behaviors, a test for $\mathrm{HCV}$ infection should be performed if this infection is suspected, especially in patients with low SES, as low SES could be a marker of undisclosed IDU. We suggest that low SES be considered along with other risk factors to define the target population for future HCV screening campaigns.

SES has been studied previously as a prognostic marker for several diseases, but not for HCV infected patients. Employment has been associated with prognosis among cirrhosis patients, with disability pensioners at particularly high risk of death. ${ }^{31}$ Among Danish cancer patients, receipt of a disability pension and low income was associated with poor prognosis, especially for short-term survival. ${ }^{25}$ Educational status was not associated with survival in our study. This contrasts with a recent study by Ly et al demonstrating that an educational level of "starting college or more" when compared to "less than high school" was protective of dying from $\mathrm{HCV}$ infection. ${ }^{57}$ In a study of liver transplantation recipients with $\mathrm{HCV}$ infection, SES was not associated with mortality or the composite endpoint "death or graft loss due to HCV". ${ }^{58}$ It is not clear why SES is associated with mortality in some settings but not in others, and why different studies find varying markers of SES associated with prognosis. It may be hypothesized that socioeconomic inequalities in mortality could be explained by material, behavioral, and psychosocial factors, with behavioral factors in particular (smoking above 20 cigarettes per day and excessive alcohol intake) being strongly associated with mortality. ${ }^{59}$ Observed effects of employment and income on prognosis could be an indirect measure of alcohol abuse, smoking, IDU, and 

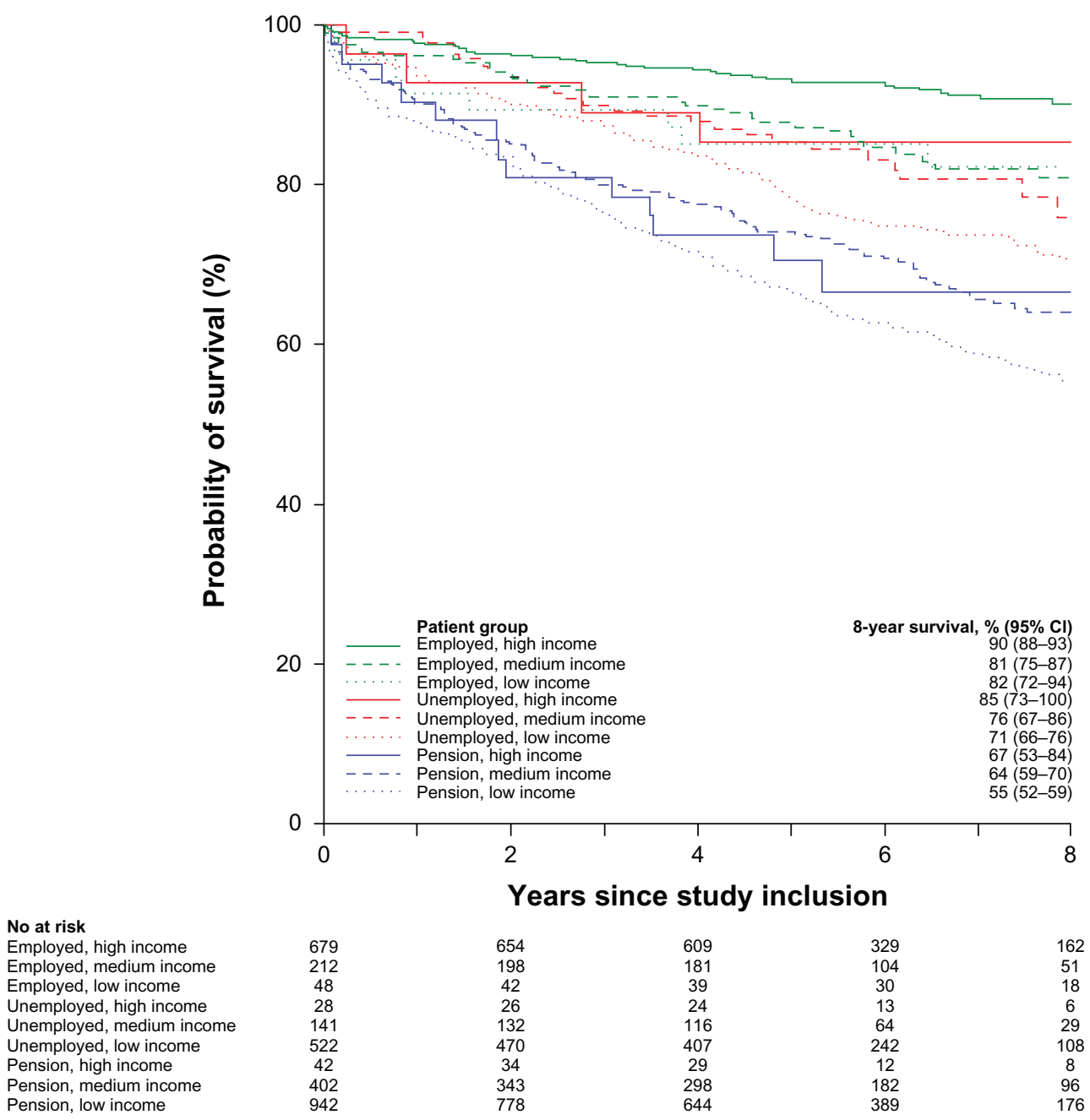

Figure 3 Survival with respect to time (years) after hepatitis $C$ virus diagnosis according to employment and income (the year before diagnosis). The five columns indicate the number of patients at risk in each patient category to the following time points: 0 years, 2 years, 4 years, 6 years and 8 years since study inclusion.

Abbreviation: $\mathrm{Cl}$, confidence intervals.

unknown risk taking behaviors not captured in our study. We speculate that HCV infected patients who are disability pensioners are less likely to receive antiviral treatment, may receive inferior treatment, or be less compliant with treatment than more affluent patients. However, it has been estimated that only $2 \%$ of Danish HCV infected patients have been treated with interferon, ${ }^{60}$ and therefore we find it unlikely that the results are substantially confounded by missing data on antiviral treatment. Noncompliant individuals may be less likely to be candidates for liver transplantation, if otherwise indicated. Whatever the underlying mechanisms are, low income $\mathrm{HCV}$ infected patients and those receiving disability pensions may benefit from more frequent follow-up visits to ensure treatment compliance and surveillance for hepatocellular carcinoma. To further address alcohol abuse, IDU and comorbidities may reduce increased mortality among these patients.
In conclusion, we found that low SES was associated with increased risk of $\mathrm{HCV}$ infection, possibly explained by undisclosed IDU. Furthermore, low SES was associated with a poor prognosis in $\mathrm{HCV}$ infected patients, with those receiving a disability pension at particularly elevated risk of death when compared to employed patients.

\section{Acknowledgment}

This study was funded by Augustinusfonden, which had no role in study design, data collection and analysis, decision to publish, or preparation of the manuscript.

\section{Disclosure}

N Obel received grants from Roche, Bristol-Meyers Squibb, Merck Sharp and Dohme, GlaxoSmithKline, Abbott, Boehringer Ingelheim, Janssen-Cilag, and Swedish-Orphan Drugs. PB Christensen received grants from Roche and 
Schering-Plough. The remaining authors declare no conflicts of interest in this work.

\section{References}

1. Choo QL, Kuo G, Weiner AJ, Overby LR, Bradley DW, Houghton M. Isolation of a cDNA clone derived from a blood-borne non-A, non-B viral hepatitis genome. Science. 1989;244:359-362.

2. World Health Organization. Hepatitis $\mathrm{C}-$ global prevalence (update). Wkly Epidemiol Rec. 1999;74:425-427.

3. Zignego AL, Ferri C, Pileri SA, Caini P, Bianchi FB. Extrahepatic manifestations of Hepatitis $C$ Virus infection: a general overview and guidelines for a clinical approach. Dig Liver Dis. 2007;39:2-17.

4. Amin J, Law MG, Bartlett M, Kaldor JM, Dore GJ. Causes of death after diagnosis of hepatitis B or hepatitis C infection: a large communitybased linkage study. Lancet. 2006;368:938-945.

5. Duberg AS, Nordstrom M, Torner A, et al. Non-Hodgkin's lymphoma and other nonhepatic malignancies in Swedish patients with hepatitis C virus infection. Hepatology. 2005;41:652-659.

6. Duberg AS, Pettersson H, Aleman S, et al. The burden of hepatitis C in Sweden: a national study of inpatient care. J Viral Hepat. 2011;18: 106-118.

7. Neal KR, Ramsay S, Thomson BJ, Irving WL. Excess mortality rates in a cohort of patients infected with the hepatitis $C$ virus: a prospective study. Gut. 2007;56:1098-1104.

8. Omland LH, Krarup H, Jepsen P, et al; DANVIR Cohort Study. Mortality in patients with chronic and cleared hepatitis $\mathrm{C}$ viral infection: a nationwide cohort study. J Hepatol. 2010;53:36-42.

9. Omland LH, Jepsen P, Krarup H, et al; DANVIR Cohort Study. Increased mortality among persons infected with hepatitis $\mathrm{C}$ virus. Clin Gastroenterol Hepatol. 2011;9:71-78.

10. Omland LH, Jepsen P, Krarup H, et al; DANVIR Cohort Study. Liver cancer and non-hodgkin lymphoma in hepatitis $\mathrm{C}$ virus-infected patients: results from the DANVIR cohort study. Int J Cancer. 2012; 130(5):2310-2317.

11. Lee MH, Yang HI, Lu SN, et al; R.E.V.E.A.L.-HCV Study Group. Chronic hepatitis $\mathrm{C}$ virus infection increases mortality from hepatic and extrahepatic diseases: a community-based long-term prospective study. J Infect Dis. 2012;206:469-477.

12. Uto H, Stuver SO, Hayashi K, et al. Increased rate of death related to presence of viremia among hepatitis $\mathrm{C}$ virus antibody-positive subjects in a community-based cohort study. Hepatology. 2009;50:393-399.

13. Omland LH, Christensen PB, Krarup H, et al; DANVIR Cohort Study. Mortality among patients with cleared hepatitis $\mathrm{C}$ virus infection compared to the general population: a Danish nationwide cohort study. PLoS One. 2011;6:e22476.

14. Hansen AB, Lohse N, Gerstoft J, et al. Cause-specific excess mortality in siblings of patients co-infected with HIV and hepatitis C virus. PLoS One. 2007;2:e738.

15. Tassiopoulos K, Bernstein J, Heeren T, Levenson S, Hingson R, Bernstein E. Hair testing and self-report of cocaine use by heroin users. Addiction. 2004;99:590-597.

16. O’Brien SF, Xi G, Yi QL, Goldman M. Understanding non-disclosure of deferrable risk: a study of blood donors with a history of intravenous drug use. Transfus Med. 2010;20:15-21.

17. Last JM. A Dictionary of Epidemiology, 4th ed. New York: Oxford University Press; 2001.

18. Perez CM, Suarez E, Torres EA, Roman K, Colon V. Seroprevalence of hepatitis $\mathrm{C}$ virus and associated risk behaviours: a populationbased study in San Juan, Puerto Rico. Int J Epidemiol. 2005;34: 593-599.

19. Dalgard O, Jeansson S, Skaug K, Raknerud N, Bell H. Hepatitis C in the general adult population of Oslo: prevalence and clinical spectrum. Scand J Gastroenterol. 2003;38:864-870.

20. Armstrong GL, Wasley A, Simard EP, McQuillan GM, Kuhnert WL, Alter MJ. The prevalence of hepatitis C virus infection in the United States, 1999 through 2002. Ann Intern Med. 2006;144:705-714.
21. Alter MJ, Kruszon-Moran D, Nainan OV, et al. The prevalence of hepatitis C virus infection in the United States, 1988 through 1994. N Engl J Med. 1999;341:556-562.

22. Meffre C, Le SY, Delarocque-Astagneau E, et al. Prevalence of hepatitis $B$ and hepatitis $C$ virus infections in France in 2004: social factors are important predictors after adjusting for known risk factors. J Med Virol. 2010;82:546-555.

23. Rothman KJ. Biases in Study Design. In: Epidemiology - An Introduction, 1st ed. Rothman KJ, editor. New York: Oxford University Press; 2002:94-112.

24. Lewis CE, Smith E, Kercher C, Spitznagel E. Predictors of mortality in alcoholic men: a 20-year follow-up study. Alcohol Clin Exp Res. 1995; 19:984-991.

25. Dalton SO, Steding-Jessen M, Gislum M, Frederiksen K, Engholm G, Schuz J. Social inequality and incidence of and survival from cancer in a population-based study in Denmark, 1994-2003: Background, aims, material and methods. Eur J Cancer. 2008;44:1938-1949.

26. Romelsjo A, Diderichsen F. Changes in alcohol-related inpatient care in Stockholm County in relation to socioeconomic status during a period of decline in alcohol consumption. Am J Public Health. 1989;79: $52-56$.

27. de Campos Lopes CB, Yamada AT, Araujo F, Pereira Barreto AC, Mansur AJ. Socioeconomic factors in the prognosis of heart failure in a Brazilian cohort. Int J Cardiol. 2006;113:181-187.

28. Hemingway H, Marmot M. Evidence based cardiology: psychosocial factors in the aetiology and prognosis of coronary heart disease. Systematic review of prospective cohort studies. BMJ. 1999;318: 1460-1467.

29. Kunst AE, del RM, Groenhof F, Mackenbach JP. Socioeconomic inequalities in stroke mortality among middle-aged men: an international overview. European Union Working Group on Socioeconomic Inequalities in Health. Stroke. 1998;29:2285-2291.

30. Mookadam F, Arthur HM. Social support and its relationship to morbidity and mortality after acute myocardial infarction: systematic overview. Arch Intern Med. 2004;164:1514-1518.

31. Jepsen P, Vilstrup H, Andersen PK, Sorensen HT. Socioeconomic status and survival of cirrhosis patients: a Danish nationwide cohort study. BMC Gastroenterol. 2009;9:35.

32. Statistics Denmark. Population and election. Population and population forecasts. Population at the first day of the quarter by municipality, sex, age, marital status, ancestry, country of origin and citizenship (FOLK1). Available from: http://www.statbank.dk/statbank5a/default. asp? $\mathrm{w}=1280$. Accessed March 20, 2013.

33. Christensen PB, Hay G, Jepsen P, et al. Hepatitis C prevalence in Denmark - an estimate based on multiple national registers. BMC Infect Dis. 2012;12:178.

34. Hansen N, Obel N, Christensen PB, et al; Danish Database for Hepatitis $\mathrm{B}$ and $\mathrm{C}$ (DANHEP) group. Effectiveness of treatment with pegylated interferon and ribavirin in an unselected population of patients with chronic hepatitis C: a Danish nationwide cohort study. BMC Infect Dis. 2011;11:177.

35. Statistics Denmark. Labour, earnings and income. Unemployment. Unemployed persons in per cent of the labour force by region, age and sex (AUP02). Available from: http://www.statbank.dk/statbank5a/ default.asp?w=1280. Accessed March 20, 2013.

36. The Central Office of Civil Registration. Available from: http://www. cpr.dk/cpr/site.aspx?p=34. Accessed March 20, 2013.

37. Krarup HB, Drewes AM, Madsen PH. A quantitative HCV-PCR test for routine diagnostics. Scand J Clin Lab Invest. 1998;58: 415-422.

38. Omland LH, Jepsen P, Skinhoj P, et al. The impact of HIV-1 co-infection on long-term mortality in patients with hepatitis C: a population-based cohort study. HIV Med. 2009;10:65-71.

39. Statistics Denmark. The Integrated Database for Labour Market Research. Available from: http://www.dst.dk/en/Statistik/dokumen tation/Declarations/integrated-database-for-labour-market-research-ida-.aspx. Accessed March 20, 2013. 
40. Statistics Denmark. SOCIO02 (high quality documentation). Available from: http://www.dst.dk/da/TilSalg/Forskningsservice/Dokumentation/ hoejkvalitetsvariable/personers-tilknytning-til-arbejdsmarkedetset-over-hele-aaret--akm-/socio02.aspx. Accessed March 20, 2013. Danish.

41. Statistics Denmark. SOCIO (high quality documentation). Avaiable from: http://www.dst.dk/da/TilSalg/Forskningsservice/Dokumentation/hoejkvalitetsvariable/personers-tilknytning-til-arbejdsmarkedetset-over-hele-aaret--akm-/socio.aspx. Accessed March 20, 2013 Danish.

42. Statistics Denmark. The Attainment Register. Available from: http:// www.dst.dk/en/Statistik/dokumentation/Declarations/the-attainmentregister.aspx. Accessed March 20, 2013.

43. The National Board of Health. Klassifikation af sygdomme [Classification of diseases]: 8th revision. Denmark: Sundhedsstyrelsen; 1986. Danish.

44. The National Board of Health. Klassifikation af sygdomme [Classification of diseases]: 10th revision. Denmark: Sundhedsstyrelsen; 1993 Danish.

45. Statens Serum Institut. The National Patient Registry (Landspatientregistret). Available from: http:/www.ssi.dk/Sundhedsdataogit/ Registre/Landspatientregisteret.aspx. Accessed March 20, 2013. Danish.

46. Statens Serum Institut. The Registry of Drug Abusers Undergoing Treatment (Register over stofmisbrugere I behandling). Available from: http://www.ssi.dk/Sundhedsdataogit/Registre/Register\%20over\%20 stofmisbrugere\%20i\%20behandling.aspx. Accessed March 20, 2013. Danish.

47. Szklo M, Nieto FJ. Basic Study Designs in Analytic Epidemiology. In: Epidemiology: Beyond the Basics, 2nd ed. Sudbury: Jones and Bartlett Publishers; 2012:3-42.

48. Pedersen J, Bjorner JB, Burr H, Christensen KB. Transitions between sickness absence, work, unemployment, and disability in Denmark 2004-2008. Scand J Work Environ Health. 2012;38:516-526.

49. Carlsen K, Harling H, Pedersen J, Christensen KB, Osler M. The transition between work, sickness absence and pension in a cohort of Danish colorectal cancer survivors. BMJ Open. 2013;3(2).
50. Charlson ME, Pompei P, Ales KL, MacKenzie CR. A new method of classifying prognostic comorbidity in longitudinal studies: development and validation. J Chronic Dis. 1987;40:373-383.

51. Sundararajan V, Henderson T, Perry C, Muggivan A, Quan H, Ghali WA. New ICD-10 version of the Charlson comorbidity index predicted inhospital mortality. J Clin Epidemiol. 2004;57:1288-1294.

52. Thygesen SK, Christiansen CF, Christensen S, Lash TL, Sorensen HT. The predictive value of ICD-10 diagnostic coding used to assess Charlson comorbidity index conditions in the population-based Danish National Registry of Patients. BMC Med Res Methodol. 2011;11:83.

53. Quan H, Sundararajan V, Halfon $P$ et al. Coding algorithms for defining comorbidities in ICD-9-CM and ICD-10 administrative data. Med Care. 2005;43:1130-1139.

54. Clayton D, Hills M. Conditional logistic regression. Statistical Models in Epidemiology, 1st ed. New York: Oxford University Press Inc; 1993:290-297.

55. The National Board of Health. Guide to the prevention of viral hepatitis. Available from: http://www.sst.dk/publ/Publ2002/hepatitis/html/index. htm. Accessed Mar 20, 2013. Danish.

56. The National Board of Health. Narkosituationen i Danmark 2010. Available from: http://www.sst.dk/publ/Publ2010/CFF/Narkotika/ NarkotikasituationenDK2010.pdf. Accessed Mar 20, 2013. Danish.

57. Ly KN, Xing J, Klevens RM, Jiles RB, Ward JW, Holmberg SD. The increasing burden of mortality from viral hepatitis in the United States between 1999 and 2007. Ann Intern Med. 2012;156:271-278.

58. Verna EC, Valadao R, Farrand E, et al. Effects of ethnicity and socioeconomic status on survival and severity of fibrosis in liver transplant recipients with hepatitis C virus. Liver Transpl. 2012;18:461-467.

59. Skalicka V, van LF, Bambra C, Krokstad S, Mackenbach J. Material, psychosocial, behavioural and biomedical factors in the explanation of relative socio-economic inequalities in mortality: evidence from the HUNT study. Int J Epidemiol. 2009;38:1272-1284.

60. Lettmeier B, Muhlberger N, Schwarzer R, et al. Market uptake of new antiviral drugs for the treatment of hepatitis C. J Hepatol. 2008;49: $528-536$. 


\section{Supplementary Materials \\ Supplementary material I}

Definitions of alcohol abuse

and injection drug use (IDU)

Alcohol abuse

A record in Danish National Registry of Patients of International Classification of Diseases (ICD)-8 codes: 291.00-291.99, 571.09, 571.10, 303.00-89, and 303.91-99 and ICD-10 codes: K70.0-K70.9, F10.2-F10.9, and G31.2 before study inclusion.

IDU

A record in Danish National Registry of Patients of ICD-8 codes: 304.09-304.99 and ICD-10 codes: F11.0-F19.9, T40.0-T40.9, and/or registration in The Registry of Drug Abusers Undergoing Treatment before study inclusion.

\section{Supplementary material 2}

Table SI Coding algorithm used for comorbid conditions in the Charlson Comorbidity Index

\begin{tabular}{|c|c|c|c|}
\hline Comorbid condition in $\mathrm{CCl}$ & ICD-8 & ICD- 10 & Score \\
\hline Myocardial infarction & 410 & $121,122,123$ & 1 \\
\hline Congestive heart failure & $\begin{array}{l}\text { 427.09, 427.10, 427.1 I, 427.19, 428.99, } \\
782.49\end{array}$ & $150,111.0,113.0,113.2$ & 1 \\
\hline Peripheral vascular disease & $440-445$ & 170-174, 177 & 1 \\
\hline Cerebrovascular disease & $430-438$ & 160-169, G45, G46 & I \\
\hline Dementia & 290.09-290.19, 293.09 & F00-F03, F05.I, G30 & 1 \\
\hline Chronic pulmonary disease & $490-493,515-518$ & $\begin{array}{l}\text { J40-J47, J60-J67, J68.4, J70.I, J70.3, J84.I, J92.0, } \\
\text { J96.I, J98.2, J98.3 }\end{array}$ & 1 \\
\hline Connective tissue disease & $712,716,734,446,139.99$ & M05, M06, M08, M09, M30-M36, D86 & 1 \\
\hline Ulcer disease & $530.91,530.98,53 \mathrm{I}-534$ & $\mathrm{~K} 22.1, \mathrm{~K} 25-\mathrm{K} 28$ & I \\
\hline Diabetes mellitus type $\mathrm{I}$ and 2 & $\begin{array}{l}249.00,249.06,249.07,249.09 \\
250.00,250.06,250.07,250.09\end{array}$ & EI0.0, EI0.I, EI0.9, EII.0, EII.I, EII.9 & I \\
\hline Hemiplegia & 344 & G8I, G82 & 2 \\
\hline Moderate to severe renal disease & $\begin{array}{l}403,404,580-584,590.09,593.19 \\
753.10-753.19,792\end{array}$ & $\begin{array}{l}\text { II 2, II3, N00-N05, N07, NII, NI4, } \\
\text { NI7-NI9, Q6I }\end{array}$ & 2 \\
\hline $\begin{array}{l}\text { Diabetes mellitus type I and } 2 \text { with } \\
\text { end organ damage }\end{array}$ & $\begin{array}{l}249.01-249.05,249.08,250.01-250.05 \\
250.08\end{array}$ & EI0.2-EI0.8, EII.2-EII.8 & 2 \\
\hline Any tumor & $140-194$ & $\mathrm{C} 00-\mathrm{C} 75$ & 2 \\
\hline Leukemia & 204-207 & $\mathrm{C} 9 \mathrm{I}-\mathrm{C} 95$ & 2 \\
\hline Lymphoma & $200-203$ & $\mathrm{C} 8 \mathrm{I}-\mathrm{C} 85, \mathrm{C} 88, \mathrm{C} 90, \mathrm{C} 96$ & 2 \\
\hline Metastatic solid tumor & $195-199$ & $\mathrm{C} 76-\mathrm{C} 80$ & 6 \\
\hline AIDS & 79.83 & B2I-B24 & 6 \\
\hline Mild liver disease* & $571,573.01,573.04$ & В।8, K70.0-K70.3, K70.9, K7I, K73, K74, K76.0 & I \\
\hline Moderate to severe liver disease* & $70.00,70.02,70.04,70.06,70.08,573.00,456$ & BI5.0, BI6.0, B।6.2, B।9.0, K70.4, K72, K76.6, 185 & 3 \\
\hline
\end{tabular}

Note: *The liver diseases of the $\mathrm{CCl}$ were not included in our comorbidity score, as they were considered as being part of the causal pathway of mortality.

Abbreviations: $\mathrm{CCl}$, Charlson Comorbidity Index; ICD, International Classification of Diseases.

\section{Publish your work in this journal}

Clinical Epidemiology is an international, peer-reviewed, open access journal focusing on disease and drug epidemiology, identification of risk factors and screening procedures to develop optimal preventative initiatives and programs. Specific topics include: diagnosis, prognosis, treatment, screening, prevention, risk factor modification, systematic reviews, risk \& safety of medical interventions, epidemiology \& biostatical methods, evaluation of guidelines, translational medicine, health policies \& economic evaluations. The manuscript management system is completely online and includes a very quick and fair peer-review system, which is all easy to use. 